Yutaka Kawano

Takeshi Noma

Izumi Yoshizawa

Kiyo Maruki

Junichi Yata

\section{Association of increased numbers of peripheral blood double-negative T-lymphocytes with elevated serum IgG levels in severely handicapped children}

Received: 21 December 1993

Accepted: 16 June 1994
Y. Kawano (®) - T. Noma · I. Yoshizawa Department of Paediatrics,

Saitama Medical School, 38 Morohongo, Moroyana, Iruma-gun, Saitama 350-04, Japan

Y. Kawano - I. Yoshizawa - K. Maruki

Moro Hospital, 38 Morohongo,

Moroyama, Iruma-gun,

Saitama 350-04, Japan

J. Yata

Department of Paediatrics, Tokyo Medical and Dental University, 1-5-45 Yushima, Bunkyo-ku, Tokyo 113, Japan
Abstract $\mathrm{CD}^{+} 4^{-} 8^{-}$double negative cells in peripheral blood lymphocytes were examined in 21 severely handicapped children divided into two groups according to serum IgG level. All children were bedridden and were taking multiple anticonvulsants and there were no apparent clinical differences between these two groups. Serum levels of $\operatorname{IgG}$ correlated well with percentages of $\mathrm{CD}^{+} 4^{-8}{ }^{-}$double negative lymphocytes in patients of both groups. In comparisons between the two groups, the high IgG group had higher counts of $\mathrm{CD}^{+} 4^{-8^{-}}$double negative lymphocytes in peripheral blood than the normal IgG group. Two distinct types of double negative cells were identified in the patients with high IgG: one had T-cell antigen receptors of $\gamma \delta$ heterodimers, the other had receptors of $\alpha \beta$ chains on their surface. As double negative T-cells are reported to have an important role in defence against bacterial infections, the increased numbers of CD3 ${ }^{+4} 4^{-8}-\mathrm{T}$-cells of both phenotypes in the high IgG patients may reflect exposure to repetitive bacterial stimuli or persistent subclinical infection which in many cases, may be undetectable clinically. Moreover, the hyperimmune states shown by the high serum IgG of these patients may result from the appearance of these unique lymphocytes because they are reported to have a helper function for $\operatorname{IgG}$ synthesis in vitro. Taken together, the increased numbers of double negative cells in patients with high IgG may reflect activated defence mechanisms and the development of hyperimmune status.

Key words Double negative T-lymphocytes - T-cell receptors Severely handicapped $\cdot \operatorname{IgG}$ level Infectious diseases

Abbreviations TCR T-cell receptors FITC fluorescein isothiocynate $P E$ phycoerythrin

\section{Introduction}

Severely handicapped children experience repeated infections which tend to be more difficult to treat than those experienced by normal healthy individuals. Elevated serum immunoglobulin levels in severely handicapped individuals may be the result of chronic subclinical inflammation [28]. Analyses of peripheral lymphocytes that would explain the cause of the increase of serum Ig in the sera of such patients have yet to be done. Existing reports on the abnormalities of lymphocyte subpopulations [37], impaired lymphocyte responses to mitogens $[18,44]$, and decreased delayed type cutaneous hypersensitivity [18] are not directly related to the overproduction of $\operatorname{IgG}$.

The role of T-cell antigen receptors (TCR) in antigen recognition has been clarified and two types of TCR have been identified [7]. Conventional heterodimeric $\alpha \beta-T C R$ are expressed by the majority of peripheral blood T-cells, most of which also co-express CD4 or CD8 as accessory 
molecules for antigen recognition. Minor populations of TCR- $\alpha \beta^{+}$cells, however, which bear neither CD4 nor CD8 [29] are called double negative T-cells. Another receptor type is TCR- $\gamma \delta$, and most T-cells that bear it are double negative [7].

Functional analyses have shown that both types of double negative cells retain potent cytotoxic activity which includes non-specific $[6,8,23,32]$ and major histocompatibility linked cytotoxicities $[10,21,36]$. Moreover, Strober et al. [43] have described natural suppressor clones of TCR- $\alpha \beta^{+} \mathrm{CD}^{+} 4^{-} 8^{-}$which show non-major histocompatability restricted inhibition of mixed lymphocyte cultures.

In addition to their cytotoxicities, TCR- $\gamma \delta^{+} \mathrm{T}$-cells respond vigorously to bacterial stimuli $[1,27]$, an indication that TCR- $\gamma \beta^{+}$T-cells function as one of the initial effectors against invading micro-organisms. Similarly, double negative TCR- $\gamma \beta^{+}$cells in mouse liver [2] and human Tcell clones of the same receptor type [33] respond to bacteria. Besides proliferative responses, double negative $\mathrm{TCR}-\gamma \delta^{+} \mathrm{T}$-cells in vitro augment antibody production both in human [38] and animal models [31].

We investigated the number of T-cell subtypes present in severely handicapped children. Because the presence or absence of infectious disease is difficult to discern in such patients, the evaluation of T-cell profiles might show a part of their immunological backgrounds, allowing us to predict the presence of underlying infectious diseases and to treat patients for such diseases and to achieve profound understanding of the hyperimmune status in these patients.

\section{Patients and methods}

Patients

Twenty-one severely handicapped patients in the Moro Hospital were divided into two groups on the basis of serum IgG levels (Table 1), Twelve patients aged 4-16 years had high IgG levels above the mean $+3 S D$ of those of age-matched controls [3]. The remaining nine patients, aged 5-17 years were assigned to the normal IgG group. None of the patients had anti-nuclear antibodies in their sera. All the children were bedridden and were receiving tube feeding because of cerebral palsy, mental retardation, epilepsy, or hydrocephalus. Patients with chromosomal abnormalities, hereditary diseases, progressive central nervous system degeneration, and metabolic disorders were excluded from this study. None of the subjects showed malnutrition, anaemia, or manifestations of active infection when examined. All had been taking multiple anticonvulsants that included phenobarbital, phenytoin, clonazepam, nitrazepam, and valproic acid for more than 4 years. Patients enrolled in this study showed respiratory infections two or three times a year and there were no significant differences between the two groups in clinical status and medication. Within several months of completion of this study, three of the patients in the high IgG group died suddenly: patients 10,12 , and 19 died of intestinal bleeding, hypothermia, and pneumonia, respectively. The study was approved by the Institutional Research and Publications Review Committee of Human Subjects of the Moro Hospital.
Flow cytometric analysis of the T-lymphocyte subset

Mononuclear cells were isolated from heparinised whole blood by Ficoll-Conray density centrifugation [9]. These cells were washed three times with phosphate-buffered saline then resuspended in

Table 1 Clinical data of the patients studied. $M$ male, $F$, female, $C P$ cerebral palsy, Epi epilepsy, $M R$ mental retardation, $H C$ hydrocephalus

\begin{tabular}{|c|c|c|c|c|c|c|}
\hline \multirow[t]{2}{*}{ Case } & \multirow[t]{2}{*}{ Sex } & \multirow[t]{2}{*}{ Age } & \multirow[t]{2}{*}{ Diseases } & \multicolumn{3}{|c|}{ Serum level (mg/dl) } \\
\hline & & & & $\operatorname{IgG}$ & $\operatorname{IgA}$ & $\operatorname{IgM}$ \\
\hline \multicolumn{7}{|c|}{ Normal IgG group } \\
\hline 1 & $M$ & 16 & $\mathrm{CP}, \mathrm{Epi}, \mathrm{MR}$ & 1560 & 446 & 348 \\
\hline 2 & M & 8 & CP, Epi, MR & 956 & 160 & 199 \\
\hline 3 & M & 14 & $\begin{array}{l}\text { CP, Epi } \\
\mathrm{MR}, \mathrm{HC}\end{array}$ & 1290 & 189 & 199 \\
\hline 4 & M & 5 & CP, Epi, MR. & 1410 & 178 & 169 \\
\hline 5 & $M$ & 17 & CP, Epi, MR & 1430 & 430 & 219 \\
\hline 6 & M & 12 & CP, Epi, MR & 1860 & 438 & 421 \\
\hline 7 & $\mathrm{~F}$ & 13 & $\mathrm{CP}, \mathrm{MR}$ & 1210 & 305 & 170 \\
\hline 8 & $F$ & 10 & CP, Epi, MR & 1410 & 112 & 226 \\
\hline 9 & $\mathrm{~F}$ & 11 & CP, Epi, MR & 1600 & 237 & 144 \\
\hline \multicolumn{7}{|c|}{ High IgG group } \\
\hline 10 & M & 12 & CP, Epi, MR & 2100 & 484 & 242 \\
\hline 11 & M & 4 & CP, Epi, MR & 1980 & 258 & 316 \\
\hline 12 & M & 6 & CP, Epi, MR & 1930 & 258 & 316 \\
\hline 13 & M & 5 & $\mathrm{CP}, \mathrm{Epi}, \mathrm{MR}$ & 1950 & 280 & 358 \\
\hline 14 & M & 13 & CP, Epi, MR & 2450 & 35.6 & 259 \\
\hline 15 & M & 5 & CP, Epi, MR & 1510 & 218 & 140 \\
\hline 16 & M & 5 & CP, Epi, MR & 1710 & 368 & 599 \\
\hline 17 & $\mathrm{~F}$ & 16 & CP, Epi, MR & 2270 & 157 & 166 \\
\hline 18 & $\mathrm{~F}$ & 13 & CP, Epi, MR, HC & 1990 & 268 & 463 \\
\hline 19 & $\mathrm{~F}$ & 13 & $\mathrm{CP}$, Epi, MR, HC & 2010 & 293 & 421 \\
\hline 20 & $\mathbf{F}$ & 16 & CP, Epi, MR & 2240 & 384 & 486 \\
\hline 21 & $\mathrm{~F}$ & 4 & CP, Epi, MR & 1880 & $<29.8$ & 159 \\
\hline
\end{tabular}

Table 2 Surface phenotype of mononuclear cells in peripheral blood from severely handicapped children

\begin{tabular}{lcc}
\hline & $\begin{array}{l}\text { Normal IgG } \\
(n=9)\end{array}$ & $\begin{array}{l}\text { High IgG } \\
(n=12)\end{array}$ \\
\hline $\mathrm{CD}^{+}$ & $73.9 \pm 7.4$ & $69.8 \pm 10.1$ \\
$\mathrm{CD}^{+}$ & $48.1 \pm 12.5$ & $41.6 \pm 14.1$ \\
$\mathrm{CD}^{+}$ & $24.8 \pm 8.0$ & $28.2 \pm 9.3$ \\
$\mathrm{CD}^{+} / \mathrm{CD}^{+}$ & $2.18 \pm 1.13$ & $1.88 \pm 1.41$ \\
$\mathrm{CD}^{+} 45 \mathrm{RA}^{+}$ & $27.5 \pm 11.5$ & $25.3 \pm 10.0$ \\
$\mathrm{CD}^{+} 45 \mathrm{RA}^{-}$ & $20.4 \pm 7.5$ & $15.6 \pm 5.8$ \\
$\mathrm{CD}^{+} 45 \mathrm{RA}^{+} / \mathrm{CD}^{+} 45 \mathrm{RA}^{-}$ & $1.50 \pm 0.80$ & $1.71 \pm 0.72$ \\
$\mathrm{CD}^{+} 11 \mathrm{~b}^{+}$ & $1.6 \pm 0.8$ & $1.9 \pm 1.1$ \\
$\mathrm{CD}^{+} 11 \mathrm{~b}^{-}$ & $22.8 \pm 8.1$ & $25.9 \pm 9.6$ \\
$\mathrm{CD}^{+} 48^{-}$ & $5.5 \pm 2.1$ & $7.9 \pm 3.2^{*}$ \\
$\mathrm{CD}^{+} 6^{+}$ & $11.4 \pm 6.4$ & $11.8 \pm 7.1$ \\
$\mathrm{CD}^{+} 6^{+}$ & $7.1 \pm 4.4$ & $5.5 \pm 3.1$ \\
\hline
\end{tabular}

Data are the means $\pm S D \%$ of positive cells for each group. $* P<0.025$ 
RPMI 1640 medium containing $0.01 \%$ sodium azide, after which they were made to react with various combinations of mouse monoclonal antibodies $(\mathrm{mAb})$. The $\mathrm{mAb}$ used were fluorescein isothiocynate (FITC)-conjugated OKT4 (CD4), OKT8 (CD8), TCR-1 (TCR- $\alpha \beta$ ), TCR $\delta-1$ (TCR- $\gamma \delta$ ), Leu 11a (CD16), Leu 18 (CD45RA), Mo 1 (CD11b) and phycoerythrin (PE)-conjugated Leu 4 (CD3), Leu 3a (CD4), Leu 2a (CD8), Leu 19 (CD56). OKT4 and OKT8 were purchased from Ortho Pharmaceutical Corp (Raritan, NJ), Leu 4, Leu 3a, Leu 2a, Leu 11a, Leu 18, Leu 19 and TCR-1 from Becton Dickinson (Mountain View, CA), Mo 1 from Coulter Immunology (Hialeah, FL) and TCR $\delta-1$ from T-cell Sciences Inc. (Cambridge, MA). CD $3^{+} 4^{-} 8^{-}$cells were identified by the combination with FITC-conjugated CD4 antibody, FITC-conjugated CD8

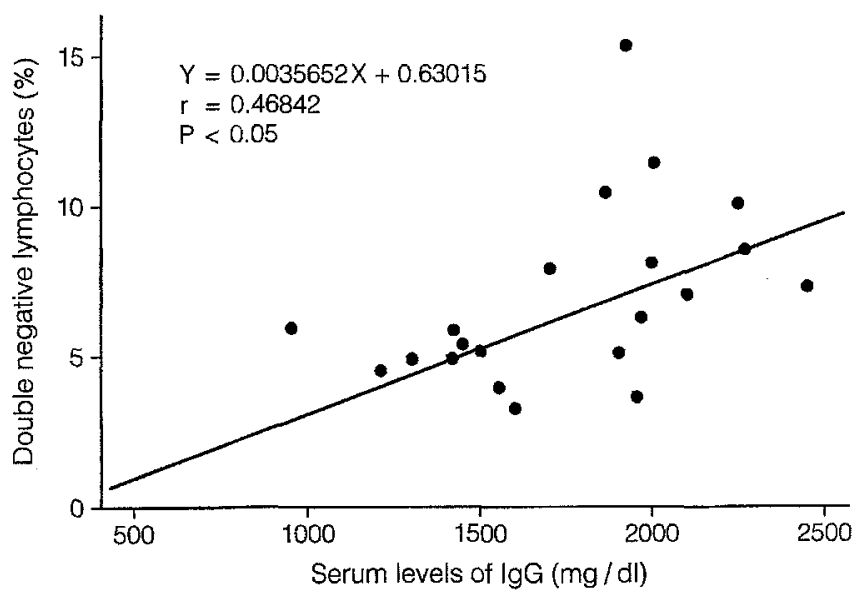

Fig. 1 Relationship between serum levels of IgG and percentages of peripheral blood $\mathrm{CD}^{+} 4-8-$ double negative lymphocytes. The linear regression line is indicated, the coefficient of correlation was 0.46872 and the slope was significantly different from zero $(P$ $<0.05)$

Fig. 2 Percents of positivity of the CD $3^{+}$TCR- $\alpha \beta^{+}$cells $(\mathbf{a})$, $\mathrm{CD}^{+} 4^{-} 8^{-}$cells $(\mathbf{b}), \mathrm{CD} 3^{+} \mathrm{TCR}-$ $\gamma \delta^{+}$cells (c), and CD4-8-TCR$\alpha \beta^{+}$cells (d) were compared for the normal $\operatorname{IgG}$ and elevated IgG groups. As shown in (a), the high IgG group had fewer CD3 $3^{+}$TCR $-\alpha \beta^{+}$cells. This compensated for the increase in $\mathrm{CD}^{+} 4^{-} 8^{-} \mathrm{T}$-cells in the former group (b). The $\mathrm{CD}^{+} 4{ }^{-}-\mathrm{T}$-cells consisted of $\mathrm{CD} 3+\mathrm{TCR}-\gamma \delta+(\mathbf{c})$ and CD4-8-TCR $\alpha \beta^{+}(\mathbf{d})$ cells, both of which appeared in larger numbers in the high IgG group. Data are means \pm SDs of the positive cells for each group antibody, and PE-conjugated CD3 antibody. Similary, CD4 8-TCR- $\alpha \beta^{+}$cells were identified by combination with PE-conjugated CD4 antibody, PE-conjugated CD8 antibody, and FITC-conjugated TCR- $\alpha \beta$ antibody. Dual colour-stained cells were analysed with a fluorescence activated cell sorter 440 (Becton Dickinson).

\section{Statistical analysis}

The two-tailed Student's $t$-test was used to analyse the data obtained for the normal and high IgG groups investigated in this study.

\section{Results}

T-cells identified by their surface expression of CD3/TCR were divided into reciprocal subpopulations of $\mathrm{CD}^{+}$ and $\mathrm{CD} 8^{+} \mathrm{T}$-cells. As shown in Table 2, we found no significant differences between the surface phenotypes of the conventional T-cell markers CD3, CD4, and CD8 of the normal IgG and high IgG groups. $\mathrm{CD}^{+}$(helper/ inducer) cells have been subdivided into $\mathrm{CD}^{+} 45 \mathrm{RA}^{+}$ (suppressor inducer) cells and $\mathrm{CD}^{+} 45 \mathrm{RA}^{-}$(helper inducer) cells, the former being reported to be the inducer of $\mathrm{CD}^{+}$suppressor cells and the latter of helper cells in pokeweed mitogen-driven Ig synthesis [24, 25]. The patients in the high IgG group did not, however, necessarily express the increase in $\mathrm{CD}^{+} 45 \mathrm{RA}^{-}$cells or decrease in $\mathrm{CD}^{+} 45 \mathrm{RA}^{+}$cells that would account for the enhanced production of IgG. The percentages of $\mathrm{CD}^{+} 45 \mathrm{RA}^{+}$cells and $\mathrm{CD}^{+} 45 \mathrm{RA}^{-}$cells in both groups were not significantly different from those of normal age-matched, non-institutionalized controls $\left(\mathrm{CD} 4{ }^{+} 45 \mathrm{RA}^{+}\right.$cells; $32.5 \pm 11.5 \%$ and $\mathrm{CD}^{+}{ }^{+} 45 \mathrm{RA}^{-}$ a $\mathrm{CD}^{+} \mathrm{TCR} \alpha \beta^{+}$

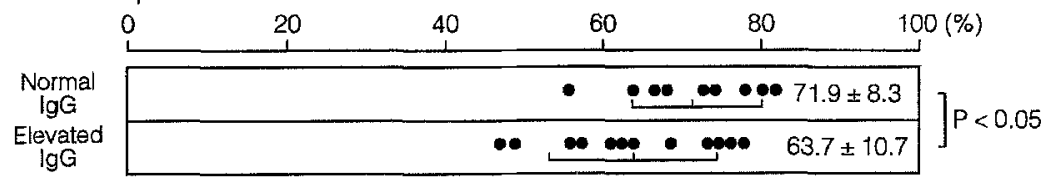

b $\mathrm{CD}^{+} 4^{-} 8^{-}$

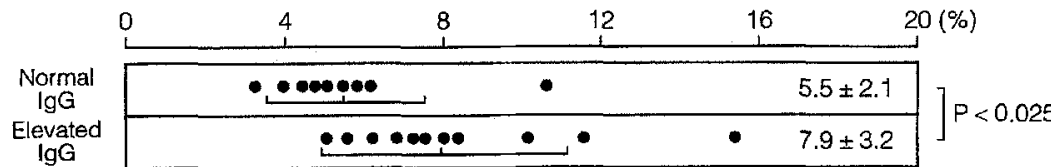

c $\mathrm{CD}^{+} \operatorname{TCF} \gamma \delta^{+}$

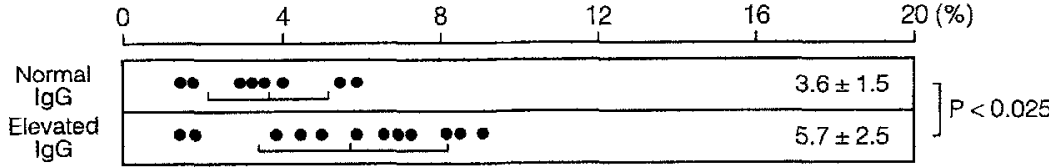

d $\operatorname{CD4}^{-} 8^{-}$TCR $\alpha \beta^{+}$

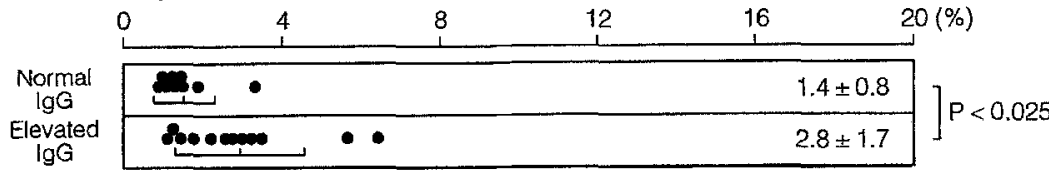


a

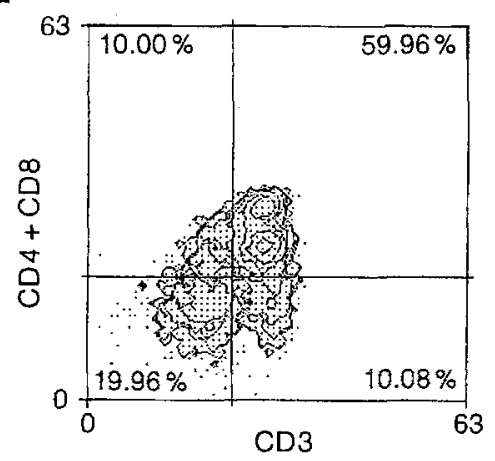

b

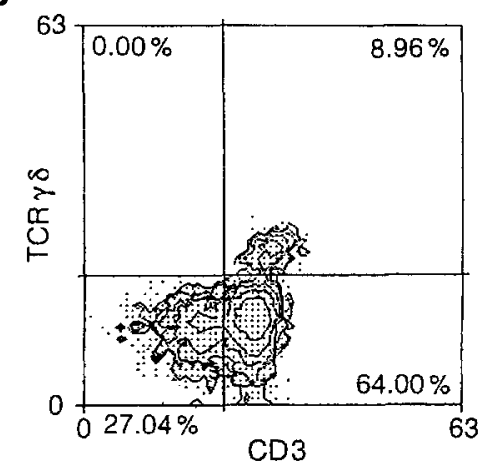

C

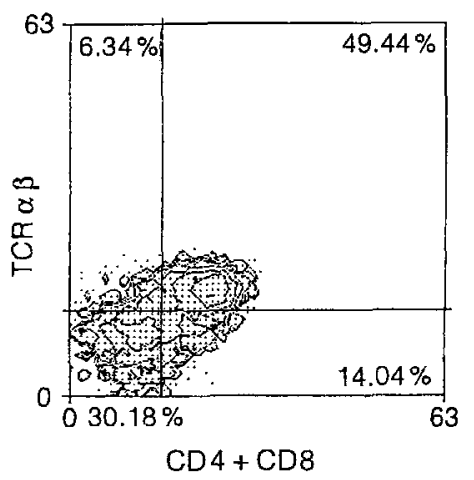

Fig. 3 Typical representations of the expression of TCR on T-cells. $\mathrm{CD}^{+} 4^{-} 8^{-}$cells $(\mathbf{a}), \mathrm{CD}^{+}{ }^{+} \mathrm{TCR}-\gamma \delta^{+}$cells $(\mathbf{b})$, and CD4-8-TCR- $\alpha \beta^{+}$ cells (c)

cells; $15.3 \pm 3.0 \%$ ). The $\mathrm{CD}^{+}$(suppressor/cytotoxic) cells were also functionally subdivided into $\mathrm{CD}^{+} 11 \mathrm{~b}^{+}$ (suppressor) and $\mathrm{CD}^{+} 11 \mathrm{~b}^{-}$(cytotoxic) cells [11], but the former cells, which should act as effector suppressor cells in antibody production, were not decreased in the high IgG group in spite of the possible enhancement of $\operatorname{IgG}$ synthesis in these patients. In addition to the T-cells, natural killer cells identified by the CD16 and CD56 antibodies were retained equally by both $\operatorname{IgG}$ groups. These findings are compatible with those of previous studies in which abnormalities of lymphocyte subsets in severely handicapped children were not clearly shown.

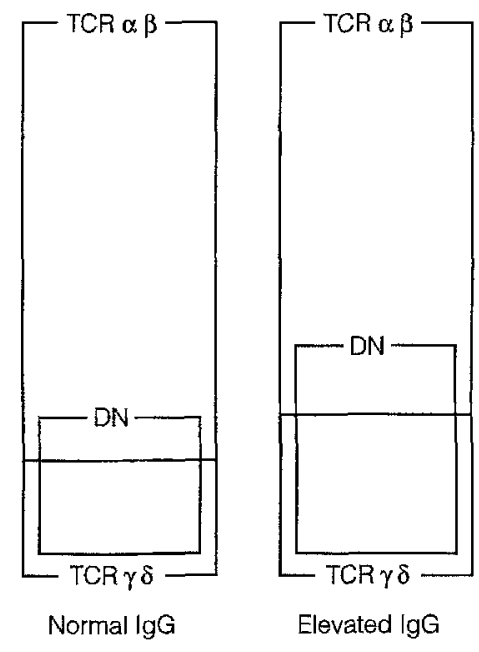

Fig. 4 Schematic drawings of the constitution of the $C D 3^{+} \mathrm{T}$-cells in normal IgG and high IgG patients. ( $D N$ double negative)

In contrast, a positive correlation was found between the percentages of $\mathrm{CD}^{+} 4^{-} 8^{-}$cells (called double negative T-cells) and serum IgG levels in all 21 patients (Fig. 1). Furthermore, this subset showed clear differences between the two groups (Fig. 2): the high IgG group expressed a statistically significant increased percentage (7.9 \pm $3.2 \%$ ) of $\mathrm{CD}^{+} 4^{-} 8^{-}$cells when compared with the normal IgG group $(5.5 \pm 2.1 \%)$. This agrees with the finding that CD $3^{+}$TCR- $\alpha \beta^{+}$cells, most of which are single positive, were decreased $(63.7 \pm 10.7 \%$ vs. $71.9 \pm 8.3 \%)$, this decrease being compensated for by an increase in $\mathrm{CD}^{+} \mathrm{TCR}-\gamma \delta^{+}$cells, most of which are double negative $(5.7 \pm 2.5 \%$ vs. $3.6 \pm 1.5 \%)$. The $\mathrm{CD}^{+} \mathrm{TCR}-\gamma \delta^{+}$ cells of several of the patients in this study expressed negligible CD8 (data not shown) which the TCR- $\gamma \delta^{+}$ cells in murine intestinal epithelium do [14]. The majority of the $\mathrm{CD}^{+} \mathrm{TCR}-\gamma \delta^{+}$cells present in the high IgG patients should be double negative T-cells. This was verified because the percentages of $\mathrm{CD}^{+} 4^{-8} 8^{-}$cells were similar to those of CD3 ${ }^{+}$TCR $-\gamma \delta^{+}$cells plus CD4-8-TCR- $\alpha \beta^{+}$ cells in each group. In our study, the high IgG group expressed an increased number of CD3 ${ }^{+} \mathrm{TCR}-\gamma \delta^{+}$cells, about $66 \%$ of the double negative T-cell population. The other $33 \%$ of the double negative $\mathrm{T}$-cells were CD4-8-TCR- $\alpha \beta^{+}$cells which were also increased in the high $\operatorname{IgG}$ group $(2.8 \pm 1.7 \%$ vs. $1.4 \pm 0.8 \%)$. Thus the two types of subpopulation that make up double negative cells were more frequent in the peripheral blood of the high IgG patients than in that of the normal IgG patients. Representative phenotypic profiles of the $\mathrm{CD}^{+} 4^{-} 8^{-}$cells (patient 20 ), CD3 ${ }^{+} \mathrm{TCR}^{-} \gamma \delta^{+}$cells (patient 20 ), and CD4-8-TCR- $\alpha \beta^{+}$cells (patient 12 ) are shown in Fig. 3. 


\section{Discussion}

Severely handicapped children are easily infected by micro-organisms that cause upper and lower respiratory tract infections. Repeated aspirations and an impaired pulmonary clearing mechanism contribute to their vulnerability. Moreover, malnutrition, medication, and long-term hospitalization may inhibit the development of a normal immune defence. However, many handicapped children have increased serum IgG levels in the absence of an active infectious disease and of anti-nuclear antibody in their sera and immunological studies have led to conflicting results $[28,37,44]$. This may be due to individual differences in the subjects studied. Underlying disease, daily activity, and medications may have affected the results of previous studies. We selected 21 patients and divided them into two groups on the basis of their serum IgG levels. These two groups were made up of age-, disease-, and medication-matched patients, all of whom were bedridden and were being tube fed. Although phenytoin has been reported to decrease Ig levels [41] and to depress cell-mediated immunity $[15,18,40]$, serum levels of IgG were not significantly correlated with the length of time or with dosage of phenytoin in our study, which is compatible with a previous study [37]. All were clinically free of active infectious diseases when examined. Furthermore, all the subjects studied had had bacterial infections that included bronchitis or pneumonia, two or three times a year.

Double negative T-cells were more frequent in the blood of the high IgG patients than in those of normal IgG patients (Table 2, Fig. 1,2). T-cells bearing TCR- $\gamma \delta$ and those bearing TCR- $\alpha \beta$ constituted the double negative cell population in the elevated IgG group (shown schematically in Fig. 4).

The functional significance of the double negative cells has yet to be fully characterized. Human beings with rheumatoid arthritis and immunodeficiencies have increased numbers of TCR- $\gamma \delta^{+}$cells in their peripheral blood $[19,26,35]$. Increased numbers of TCR- $\gamma \delta^{+}$cells have been found in necrotic areas of Kikuchi and tuberculous lymphadenitis [12] as well as in granulomatous lesions of leprosy and leishmaniasis [22]. Increased numbers of TCR- $\gamma \delta^{+}$cells have also been reported in intra-epithelial lymphocytes taken from the gut of patients with coeliac and inflammatory bowel diseases [42, 45]. In our experience, TCR- $\gamma \delta^{+}$cells were increased in the peripheral blood in patients with chronic inflammatory bowel disease, which is compatible with the previous report [16]. In in vitro experiments, double negative T-cells that expressed TCR- $\gamma \delta$ predominantly proliferated in response to bacteria [1], Mycobacterium [27], and $65 \mathrm{kDa}$ mycobacterial heat shock protein (Hsp65) [5]. These results suggest that TCR- $\gamma \delta^{+}$T-cells function as the major component of primary defence mechanisms. As stress proteins are well conserved in the phylogeny from prokaryocytes to eukaryocytes $[20,47]$, it is reasonable that TCR- $\gamma \delta^{+} \mathrm{T}$ cells are also capable of responding to heat shock protein of self cells induced by high temperature [34]. These findings suggest that bacterial infection may induce self heat shock protein because of the high temperature they bring about and may amplify the proliferation of TCR- $\gamma \delta^{+} \mathrm{T}-$ cells in the patients of our high IgG group.

Like the TCR- $\gamma \delta^{+}$T-cells in human auto-immune diseases and immunodeficiencies, $\mathrm{CD}^{+} 4^{+} 8^{-}$TCR- $\alpha \beta^{+} \mathrm{T}-$ cells were increased in the spleens of auto-immune mice [17] and in the peripheral blood of patients with systemic lupus erythematosus [38] and those with immunodeficiencies [46]. Investigations of double negative T-cells have related these cells to the major causes of auto-immune diseases. Results of one study suggested that the helper function is retained by double negative TCR $\alpha \beta^{+}$cells with respect to immunoglobulin production [31]. In our in vitro experiments, double negative T-cells failed to help immunoglobulin synthesis in the presence of pokeweed mitogen (data not shown). These results may not suggest the lack of helper activity in double negative T-cells, because double negative T-cells may require the presence of other T-cells to express their helper function.

In addition to the helper function, increased TCR- $\alpha \beta^{+}$ cells of the double negative phenotype in the livers of mice injected with bacteria are self-reactive and are suggested to be beneficial for the surveillance of autologous bacteria-infected cells [2]. Moreover, in human beings, evidence has been presented that CD4-8 ${ }^{-}$TCR- $\alpha \beta^{+}$cells are activated by bacterial superantigens [33]. As superantigens may initiate auto-immune disease $[13,30]$, double negative lymphocytes activated by superantigens in severely handicapped children may reflect the activated immune status. The activated immune system will predispose to the auto-immune disease, although none of the patients in our study were positive for serum anti-nuclear antibody despite a high incidence of systemic lupus erythematosus in patients receiving anticonvulsants $[4,39]$.

Taking into account these findings, the increase of double negative T-cells of both TCR types found in the high IgG patients may reflect activation of the body's defence mechanism against a micro-organism which is infecting the person. Thus the increase in double negative T-cells that have the potential to react with microbial superantigens may assist B-cells to produce immunoglobulins, as evidenced by the superantigens that mediate T-helper-B-cell interactions [13].

Furthermore, the fact that three patients in the high $\operatorname{IgG}$ group died after the completion of this study suggests that an increase in double negative cells may herald future aggravation of a patient's condition.

The increase in double negative cells seen in high IgG patients offers a new immunological dimension by which to investigate the defence mechanisms and the development of auto-immune disease-like phenomenon of severely handicapped children.

Acknowledgements We thank Ms Patricia Yamada for editing the English. 
References

1. Abo T, Sugawara S, Seki S, Fujii M, Rikiishi H, Takeda K, Kumagai K (1990) Induction of human TCR $\gamma \delta^{+}$ and TCR $\gamma \delta^{+} \mathrm{CD} 2^{+} \mathrm{CD} 3^{-}$double negative lymphocytes by bacterial stimulation. Int Immunol 8:775-786

2. Abo T, Ohteki T, Seki S, Koyamada N, Yoshikai Y, Matsuda T, Rikiishi H, Kumagai K (1991) The appearance of $T$ cells bearing self-reactive $T$ cell receptor in the livers of mice injected with bacteria. J Exp Med 174:417-424

3. Allansmith $\mathrm{M}$, McClellan BH, Butterworth M, Maloney JR (1968) The development of immunoglobulin levels in man. Pediatrics 72:276-290

4. Benton JW, Tynes B, Register HB, Alford C, Holley HL (1962) Systemic lupus erythematosus occurring during anticonvulsive drug therapy. JAMA 180: 115-118

5. Born W, Hall L, Dallas A, Boymel J, Shinnick T, Young D, Brennan P, O'Brien R (1990) Recognition of a peptide antigen by heat shock-reactive $\gamma \delta$ T lymphocytes. Science 249:67-69

6. Borst J, Griend RJ van de, Oostveen JW van, Ang S, Melief CJ, Seidoman JG, Bolhuis RLH (1987) A T-cell receptor $\gamma / \mathrm{CD} 3$ complex found on cloned functional lymphocytes. Nature 325 : 683-688

7. Brenner MB, Mclean J, Dialynas DP, Strominger JL, Smith JK, Owen FL, Seidoman JG, Stephen IP, Rosen F, Krangel MS (1986) Identification of a putative second $T$ cell receptor. Nature 332: 145-149

8. Brenner MB, Mclean J, Scherft H, Riberdy J, Ang S, Seidoman JG, Delvlin P, Krangel MS (1987) Two forms of the T-cell receptor $\gamma$ protein found on peripheral blood cytotoxic $T$ lymphocytes. Nature 325:689-694

9. Böyum A (1968) A one-stage procedure for isolation of granulocytes and lymphocytes from human blood. General properties of white blood cells in a $1 \mathrm{~g}$ gravity field. Scand Clin Lab Invest 21 [Suppl] 54-76

10. Ciccone E, Viale O, Bottino C, Pende D, Migone N, Cosorati G, Tamhussi $G$, Moretta A, Moretta L (1988) Antigen recognition by human $\mathrm{T}$ cell receptor $\gamma$-positive lymphocytes. J Exp Med 167: 1517-1522

11. Clement LT, Grossi CE, Gartland GL (1984) Morphologic and phenotypic features of the subpopulation of Leu $2^{+}$ cells that suppresses T cell differentiation. J Immunol 133:2461-2468
12. Falini B, Flenghi L, Pileri $S$, Pelicci $P$, Fagioli M, Martelli MF, Moretta L, Ciccone $E(1989)$ Distribution of T cells bearing different forms of the $\mathrm{T}$ cell receptor $\gamma / \delta$ in normal and pathological human tissues. J Immunol 143: 2480-2488

13. Friedman SM, Posnett DN, Tumang JR, Cole BC, Crow MK (1991) A potential role for microbial superantigens in the pathogenesis of systemic autoimmune disease. Arthritis Rheum 34: $468-480$

14. Goodman T, Lefrancois L (1988) Expression of the $\gamma-\delta$ T-cell receptor of intestinal CD8 ${ }^{+}$intraepithelial lymphocytes. Nature $333: 855-858$

15. Grob PJ (1972) Immunological abnormalities and hydantoins. BMJ 3 : 561-563

16. Hara T, Matsumoto T, Mizuno $\mathrm{Y}$, Nishizaki M, Ueda K, Motooka M, Kimura N, Oshimi K, Ohga S, Yoshikai Y (1993) Peripheral expansion of gamma delta $\mathrm{T}$ cell receptorpositive cells in a patient with Crohn's disease. Acta Pediatr Jpn 35:45-48

17. Hashimoto $Y$, Yui K, Littman D, Green M (1987) T-cell receptor genes in autoimmune mice: T-cell subsets have unexpected $\mathrm{T}$-cell receptor gene programs. Proc Natl Acad Sci USA 84 :5883-5887

18. Higashi A, Matsuda I, Sinosuka S, Ohtsuka H, Endo F, Maeda T, Ikeda T, Miyoshino S (1978) Delayed cutaneous hypersensitivity in children with severe multiple handicaps treated with phenytoin. Eur J Pediatr 129:273-278

19. Holoshitz J, Konong F, Coligan JE, De Bruyn J, Strober S (1989) Isolation of CD4-CD8 mycobacterium-reactive $\mathrm{T}$ lymphocyte clones from rheumatoid arthritis synovial fluid. Nature 339 : 226-229

20. Kaufmann SHE (1990) Heat shock proteins and the immune response. Immunol Today $11: 129-136$

21. Matis LA, Cron R, Bluestone JA (1987) Major histocompatibility complex-linked specificity of $\gamma \delta$ receptorbearing T lymphocytes. Nature 330 : 262-264

22. Modlin RL, Pirmez C, Hofman FM, Torigian V, Uyemura K, Rea TH, Bloom BR, Brenner MB (1989) Lymphocytes bearing antigen-specific $\gamma \delta \mathrm{T}$ cell receptors accumulate in human infectious disease lesions. Nature 339: $544-548$
23. Moingeon $\mathrm{P}$, Jitsukawa $S$, Faure $F$, Troalen F, Triebel F, Graziani M Forestier F, Bellet D, Bohunon C, Hercend T (1987) A $\gamma$-chain complex forms a functional receptor on cloned human lymphocytes with natural killerlike activity. Nature 325:723-726

24. Morimoto C, Letvin NL, Distaso JA, Aldrich WR, Schlossman SF (1985) The isolation and characterization of the human suppressor inducer $\mathrm{T}$ cell subset. J Immunol 134 : 1508-1515

25. Morimoto C, Letvin NL, Boyd AW, Hagan M, Brown HM, Kornacki MM, Schlossman SF (1985) The isolation and characterization of human helper inducer T cell subset. J Immunol 134: 3762-3769

26. Morio T, Takase K, Okawa H, Oguchi M, Kanbara M, Hiruma F, Yoshino K, Kaneko T, Asamura S, Inoue T, Tsuji Y, Tasaka H, Kakei I, Miyata T, Yata J (1989) The increase of non-MHC-restricted cytotoxic cells $(\gamma / \delta$-TCR-bearing $\mathbf{T}$ cells or NK cells) and the abnormal differentiation of $B$ cells in Wiscott-Aldrich syndrome. Clin Immunol Immunopathol 52:279-290

27. O'Brien RL, Happ MP, Dallas A, Palmer E, Kubo R, Born WK (1989) Stimulation of major subset of lymphocytes expressing $T$ cell receptor by an antigen derived from mycobacterium tuberculosis. Cell 57: 667-674

28. Ohara $Y$, Wakiguchi $H$, Kurashige $T$ (1989) Immunological studies of severe mentally and physically handicapped patients: grade for disturbance in motor function as the most important factor of abnormal immunity. Jpn J Pediatr $93: 1507-1512$

29. Palacios R, Studer S, Samaridis J, Pelkonen J (1989) Thymic epithelial cells induce in vitro differentiation of pro-T lymphocyte, clones into TCR alpha, beta/T3+ and TCR gamma, delta/T3+ cells. EMBO J 8:4053-4063

30. Paliard X, West SG, Lefferty JA, Clements JR, Kappler JW, Marrack P, Kotzin BL (1991) Evidence for the effects of a superantigen in rheumatoid arthritis. Science 253:325-329

31. Pelkonen J, Palacios R (1990) LD1: a $\mathrm{CD}^{-}{ }^{-\mathrm{CD}} 8^{-}{ }^{-} \mathrm{TCR} \alpha \beta / \mathrm{CD}^{+}$peripheral $\mathrm{T}$ cell line with helper function for $B$ lymphocytes. Int Immunol 6:555-562

32. Porcelli S, Brenner MB, Grenstein JL, Balk SP, Terhost C, Bleicher PA (1989) Recognition of a cluster of differentiation 1 antigens by human CD4-CD8- cytotoxic T lymphocytes. Nature $341: 447-450$ 
33. Quaratino S, Murison G, Knyba RE, Verhoef A, Londei M (1991) Human CD4- CD8 $-\alpha \beta^{+} \mathrm{T}$ cells express a functional $\mathrm{T}$ cell receptor and can be activated by superantigens. J Immunol 147:3319--3323

34. Rajasekar R, Sim G, Augustin A (1990) Self heat shock and $\gamma \delta$ T-cell reactivity. Proc Natl Acad Sci USA 87: 1767-1771

35. Reme T, Poetier M, Fraysinoux F, Conbe B, Miossec P, Fovier F, Sany J (1990) $\mathrm{T}$ cell receptor expression and activation of synovial lymphocyte subsets in patients with rheumatoid arthritis. Arthritis Rheum $33: 485-492$

36. Rivas A, Koide J, Laus R, Engelman EG (1990) Alloantigen-specific cytotoxic clones bearing the $\alpha, \beta \mathrm{T}$ cell antigen receptor but not CD4 or CD8 molecules. J Immunol 145:470-476

37. Shibuya A, Morooka K (1976) Lymphocyte subpopulations and serum immunoglobulin levels in the patients under long term anticonvulsant therapy. Brain Dev 8:368-372

38. Shivakumar S, Tsokos GC, Datta SK (1989) T cell receptor $\alpha / \beta$ expressing double negative (CD4-/CD8 ${ }^{-}$) and $\mathrm{CD}^{+} \mathrm{T}$ helper cells in humans augment the production of pathogenic anti-DNA autoantibodies associated with lupus nephritis. J Immunol 143: 103-112
39. Singsen BH, Fishman L, Hanson $V$ (1976) Antinuclear antibodies and lupus-like syndromes in children receiving anticonvulsants. Pediatrics 57: 529-534

40. Sorrell TC, Forbes IJ (1975) Depression of immune competence by phenytoin and carbamazepin. Clin Exp Immunol 20:273-285

41. Sorrell TC, Forbes IJ, Burness FR (1971) Depression of immunological function in patients treated with phenytoin sodium (sodium diphenylhydantoin). Lancet I : 1233-1235

42. Spencer J, Isaacson PG, Diss TC, MacDonald TT (1989) Expression of disulfide-linked and non-disulfide-linked forms of the T cell receptor $\gamma / \delta$ heterodimer in human intestinal intraepithelial lymphocytes. Eur J Immuno 19 : 1335-1338

43. Strober S, Jones SD, Vlasselaer $P$ van, Duwe G, Salimi S, Allison JP (1989) Cloned natural suppressor cell lines express the $\mathrm{CD}^{+}{ }^{+} \mathrm{CD} 4^{-} \mathrm{CD}^{-}$surface phenotype and the $\alpha, \beta$, heterodimer of the $T$ cell antigen receptor. $J$ Immunol 143: 1118-1122

44. Tamagawa $\mathrm{K}$, Hasegawa $\mathrm{H}$, Hayashi $\mathrm{N}$, Ishihara K (1976) Investigation on high incidence of infections in severely handicapped children. Brain Dev 7: 300-307
45. Trejdosiewicz LK, Calabrese A, Smart CJ, Oakes DJ, Howdle PD, Crabtree JE, Losowski MS, Lancaster LF, Boylston AW (1991) $\gamma \delta \mathrm{T}$ cell receptor-positive cells of the human gastrointestinal mucosa: occurrence and $\mathrm{V}$ region gene expression in Heliobacter pyloriassociated gastritis, coeliac disease and inflammatory bowel disease. Clin Exp Immun 84:440-444

46. Wirt DP, Brooks EG, Vaidya $S$, Klimpel GR, Waldmann TA, Goldblum RM (1989) Novel T-lymphocyte population in combined immunodeficiency with features of graft-versushost disease. N Engl J Med 321 : 370-374

47. Young D, Lathiigra R, Hendrix R, Sweetster D, Young RA (1988) Stress proteins are immune targets in leprosy and tuberculosis. Proc Natl Acad Sci USA $85: 4267-4270$ 